Vol 11, Issue 11, 2018

\title{
DESIGN AND CHARACTERIZATION OF MICROEMULSION GEL FOR TRANSDERMAL DRUG DELIVERY SYSTEM OF DULOXETINE HYDROCHLORIDE
}

\author{
KARISHMA TOLE*, GANESH DESHMUKH \\ Department of Pharmaceutics, Oriental College of Pharmacy, Sanpada, Navi Mumbai - 400705, Maharastra, India. \\ Email: karutole@gmail.com
}

Received: 26 May 2018, Revised and Accepted: 03 July 2018

\section{ABSTRACT}

Objective: The objective was to improve the bioavailability, stability of formulation, and skin permeability of Duloxetine HCl.

Method: Microemulsion was prepared with oleic acid as oil, water, and $\mathrm{S}_{\text {mix }}$ ratio of tween 20 to propylene glycol (1:3). Pseudo-ternary phase diagrams were constructed to determine the region of existence of microemulsions prepared using oil titration method. Optimization of formulations was done based on the in vitro diffusion studies. The microemulsion was gelled using carbopol 934p and HPMCK 100 as the gelling agent.

Result: After the analysis of different evaluation parameter and drug release, the F3 batch was selected as a promising formulation for delivery of duloxetine $\mathrm{HCl}$ as a microemulsion gel for transdermal drug delivery with $79.607 \%$ drug release in $10 \mathrm{~h}$.

Conclusion: It was observed that transdermal microemulsion gel can be formulated successfully for duloxetine $\mathrm{HCl}$ with improved bioavailability. Among the other batches, the F3 batch was selected as an optimized batch because all the evaluation parameters results are satisfactory. From stability data, the formulation was found to be stable as no phase separation or turbidity was observed in the formulation after 3 months.

Keywords: Transdermal, Duloxetine $\mathrm{HCl}$, Microemulsion gel, Phase diagrams.

(C) 2018 The Authors. Published by Innovare Academic Sciences Pvt Ltd. This is an open access article under the CC BY license (http://creativecommons. org/licenses/by/4. 0/) DOI: http://dx.doi.org/10.22159/ajpcr.2018.v11i11.27552

\section{INTRODUCTION}

Transdermal drug delivery offers many advantages over other traditional routes; however, the barrier nature of the skin made it difficult for most of the drugs to be delivered through it [1]. Transdermal drug delivery system has several advantages such as ability to deliver the drug into systemic circulation by avoiding firstpass metabolism, avoids drug degradation in the gastrointestinal tract, and improves bioavailability [2]. A remarkably broad range of transdermal formulations is available, ranging from simple solutions and lotions, though commonly used creams, ointments, gels, and patches. While selecting a suitable dosage form drug, physicochemical properties such as solubility, pKa, and lipophilicity must be taken into consideration [3-5]. Duloxetine $\mathrm{HCl}$ (Fig. 1) [N-methyl- $\gamma-(1-$ naphthyloxy)-2-thiophenepropylamine] is a selective serotonin and noradrenaline reuptake inhibitor, approved by the USFDA for the treatment of major depressive disorders [6]. Microemulsion gel, as the name suggests they are the combination of microemulsion and gel. The term "microemulsion" refers to a thermodynamically stable, isotropic clear dispersion of two immiscible liquids, such as oil and water, which is stabilized by an interfacial film of surfactant and cosurfactant molecules [7]. In fact, the presence of a gelling agent in the water phase converts a classical emulsion into a microemulsion-based gel. The direct oil-in-water system is used to entrap lipophilic drugs, whereas hydrophilic drugs are encapsulated in the reverse water-inoil system. Microemulsions possess a certain degree of elegance and are easily washed off whenever desired. They also have a high ability to penetrate the skin.

\section{MATERIALS AND METHODS}

Duloxetine $\mathrm{HCl}$ was a gift sample from CTX Life science Pvt. Ltd., Gujarat. HPMCK100, Propylene glycol, $\mathrm{NaOH}$ were procured from Chemdyes Corporation, Gujarat. Carbopol 934p and oleic acid were procured from Research Lab Finchem, India. Tween 20 was procured from Encore
Chemicals. Methanol was procured from Thomas Baker Pvt. Ltd., India. All reagents used were of analytical grade.

\section{Methods}

Solubility studies [8-11]

The solubility of duloxetine $\mathrm{HCl}$ was determined in various excipients such as oils, surfactant, and cosurfactant. Excess amount of duloxetine $\mathrm{HCl}$ was added to $2 \mathrm{ml}$ of each excipient and vortex-mixed. They were stirred in a rotary shaker at $37 \pm 0.5^{\circ} \mathrm{C}$. All samples were centrifuged at 3000 RPM for 15 min using a laboratory centrifuge. The supernatant was filtered, suitably diluted with methanol, and analyzed spectrophotometrically at $\lambda_{\max }$ of $290 \mathrm{~nm}$ using a Double beam UV-Visible spectrophotometer.

\section{Construction of ternary phase diagram [12]}

Pseudoternary phase diagrams comprises oil, $S_{\text {mix }}$ and water were developed using the oil titration method, specific ratio of $S_{\text {mix }}$ $(1: 1,1: 2,1: 3,2: 1$, and $3: 1)$, water were taken in test tubes and vortexed for $5 \mathrm{~min}$ followed by addition of oil with a micropipette, the addition of oil was continued until addition of one more drop produce turbidity. They were also visually observed for phase clarity and flowability. The volume of oil phase was noted, and phase diagrams were then constructed using chemix software.

\section{Formulation of microemulsions [13]}

The microemulsion formulations were prepared using oleic acid as oil phase, Tween 20 as a surfactant and propylene glycol as cosurfactant based on the solubility studies, as the drug was having the highest solubility in these solvents. The ratios were selected from the constructed pseudo-ternary phase diagrams. Using the oil phase titration method microemulsions were prepared. Microemulsions were prepared by mixing the surfactant mixture and aqueous phase at the constant stirring rate. The drug was added to the oil phase, and methanol was added to enhance the solubility of drug in oil phase, 
followed by dropwise addition of oil phase to aqueous phase at constant stirring rate until microemulsions were formed.

\section{Formulation of microemulsion gels}

Microemulsions were prepared, and then HPMC K100 and Carbopol $934 \mathrm{p}$ were added to it. This mixture was then kept for soaking to $24 \mathrm{~h}$. Next day $\mathrm{pH}$ of the gels was adjusted using $\mathrm{NaOH}$ solution. Compositions of duloxetine $\mathrm{HCl}$ loaded microemulsion gels are given in Table 1.

\section{Characterization of microemulsion gel}

\section{Appearance}

The prepared formulation was inspected visually for their color, appearance, and consistency.

\section{$p H$}

The $\mathrm{pH}$ values of formulations were measured by a $\mathrm{pH}$ meter. The $\mathrm{pH}$ meter was calibrated before each use with buffer solution of $\mathrm{pH} 4.0,7.0$, and 9.0. The measurement of $\mathrm{pH}$ of the formulation was done [14].

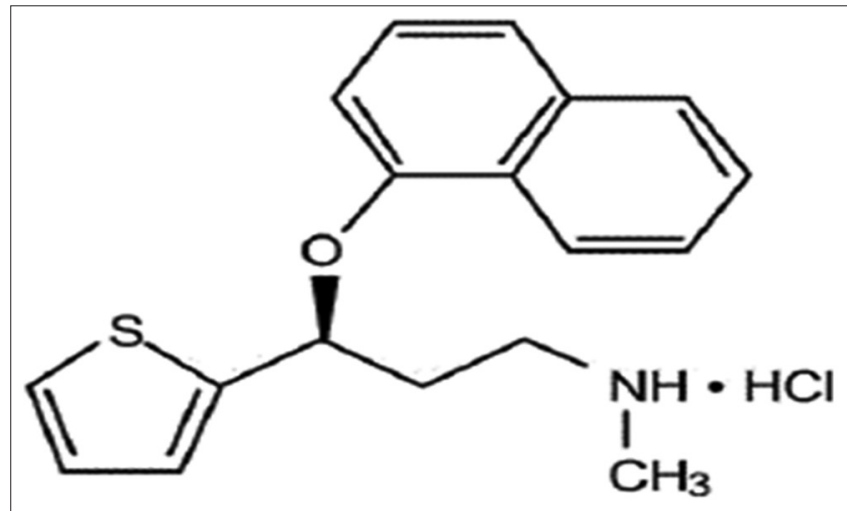

Fig. 1: Duloxetine $\mathrm{HCl}$ drug structure

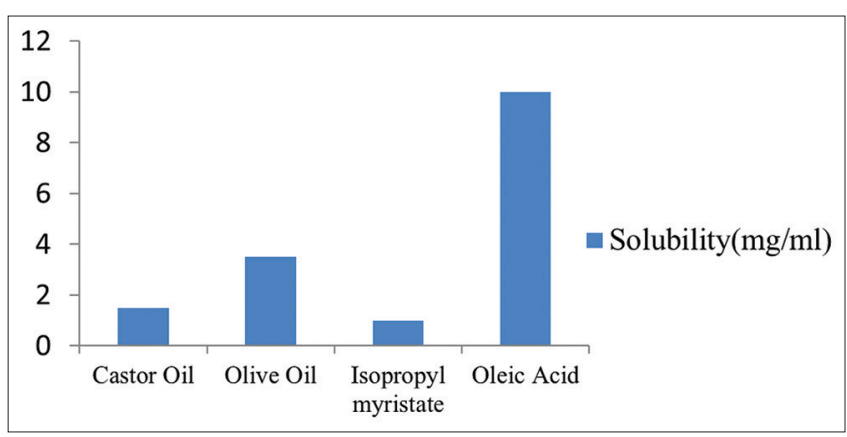

Fig. 2: Solubility of drug in different oils

\section{Viscosity}

The viscosities of formulations were measured with a Brookfield Viscometer DV-II+PRO, equipped with spindle no. LV1 and spindle code 61. The spindle was dipped in the preparation and rotated at ambient temperature at $100 \mathrm{RPM}$ for $5 \mathrm{~min}$ [15].

\section{Globule size and zeta potential}

The mean droplet size and zeta potential were determined by photon correlation spectroscopy using the Zetasizer (Malvern Instruments, UK). Each sample was diluted to a suitable concentration with filtered double-distilled water. Globule size analysis was performed at $25^{\circ} \mathrm{C}$ with an angle of detection at $90^{\circ} \mathrm{C}$. Size and zeta potential of formulations were obtained directly from the instrument [14].

\section{Spreadability}

Two glass slides were taken, and onto one slide, an excess of $3 \mathrm{~g}$ of gel was placed. Then, another glass slide was placed such that gel sandwiched between two glass slides. The top slide was subjected to a stress of $50 \mathrm{~g}$ by putting weight on it. Then, the time (in seconds) required by the gel to travel a distance of $10 \mathrm{~cm}$ was noted. A shorter time interval indicates better spreadability [13].

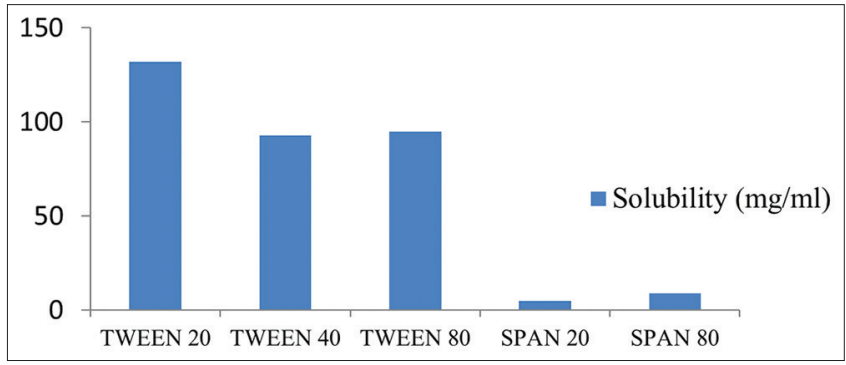

Fig. 3: Solubility of drug in surfactants

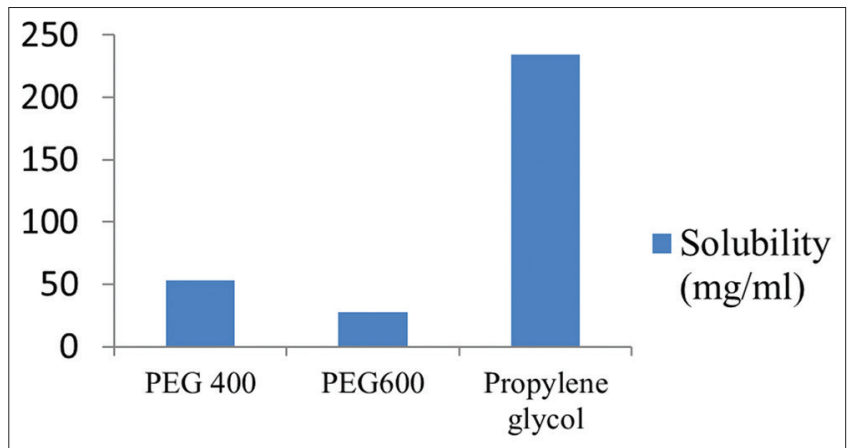

Fig. 4: Solubility of drug in cosurfactants

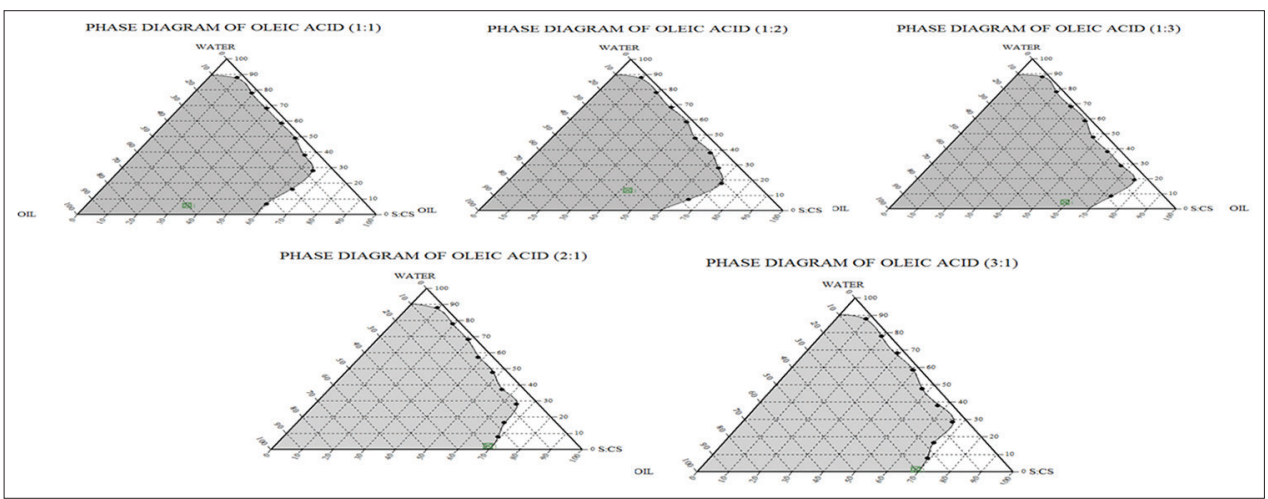

Fig. 5: Phase diagram of oleic acid in different ratios of Tween 20 and propylene glycol 


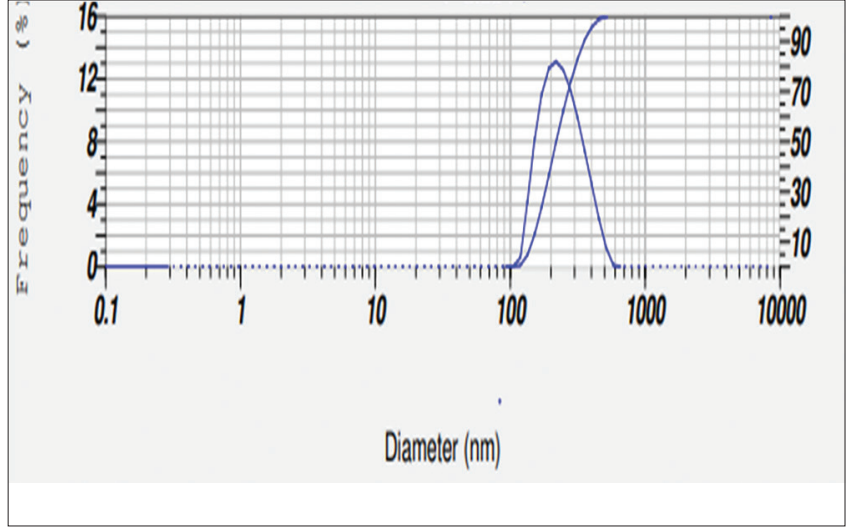

Fig. 6: Globule size of optimized batch F3

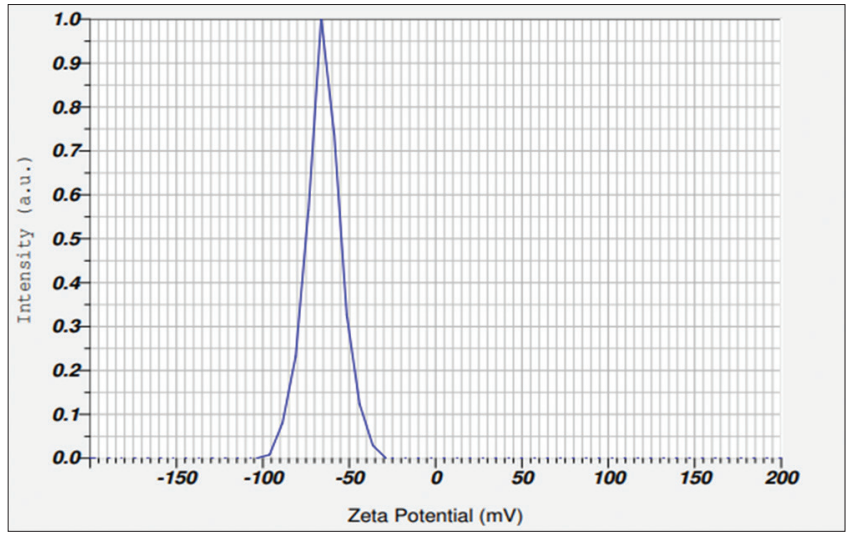

Fig. 7: Zeta potential of optimized batch F3

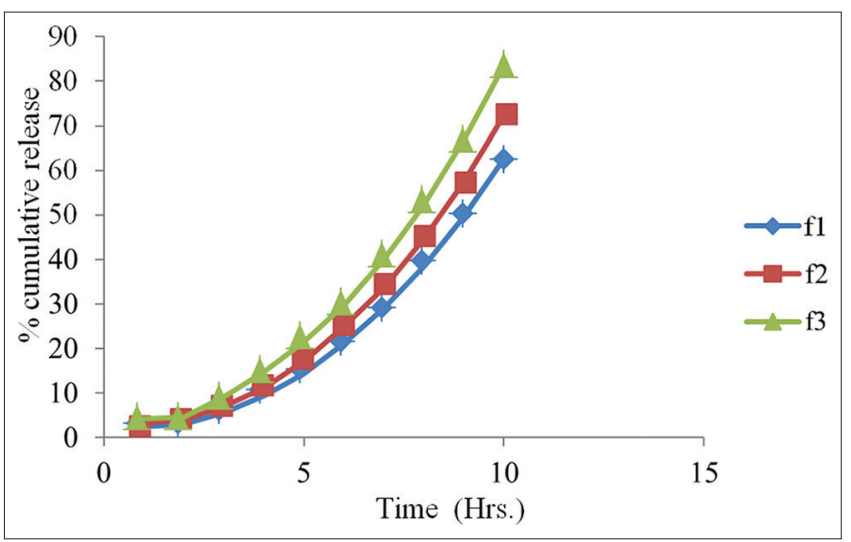

Fig. 8: Cumulative \% drug release of F1- F3 formulation

In-vitro drug release studies [13]

Drug release studies were performed using Franz diffusion cell employing a Millipore membrane (Millipore membrane $0.45 \mu \mathrm{m}$ ). Millipore membrane was initially soaked in $\mathrm{pH} 7.4$ phosphate buffer solution for $24 \mathrm{~h}$. It was then clamped between the donor and receptor compartments of the Franz diffusion cell. The receptor compartment was filled with $\mathrm{pH} 7.4$ phosphate buffer solution and was magnetically stirred throughout the experiment at 100 RPM. The donor compartment contained an appropriate amount ( $2 \mathrm{~g}$ ) of the formulation. Aliquots $(1 \mathrm{ml})$ of sample were withdrawn from the receptor compartment at specified time intervals for $10 \mathrm{~h}$ and were replaced with fresh buffer solution to maintain sink conditions. The samples were analyzed for drug concentration using UV-Visible double beam spectrophotometer at $289 \mathrm{~nm}$. The drug concentration was calculated using the standard calibration curve.
Table 1: Composition of microemulsion gel formulation

\begin{tabular}{llll}
\hline Ingredients & F1 & F2 & F3 \\
\hline Duloxetine HCl & $0.115 \mathrm{~g}$ & $0.4 \mathrm{~g}$ & $1.1 \mathrm{~g}$ \\
Oleic acid & $11.5 \mathrm{ml}$ & $11.1 \mathrm{ml}$ & $9 \mathrm{ml}$ \\
Tween 20: PG (1:3) & $55.7 \mathrm{ml}$ & $58 \mathrm{ml}$ & $63.6 \mathrm{ml}$ \\
Water & $33 \mathrm{ml}$ & $31 \mathrm{ml}$ & $27.3 \mathrm{ml}$ \\
Methanol & - & $1 \mathrm{ml}$ & $1 \mathrm{ml}$ \\
HPMC K100 & $0.6 \mathrm{~g}$ & $0.6 \mathrm{~g}$ & $0.6 \mathrm{~g}$ \\
Carbopol 934p & $1 \mathrm{~g}$ & $1 \mathrm{~g}$ & $1 \mathrm{~g}$ \\
NaOH & q.s. & q.s. & q.s. \\
Total & $100 \mathrm{~g}$ & $100 \mathrm{~g}$ & $100 \mathrm{~g}$ \\
\hline
\end{tabular}

Table 2: Evaluation of Microemulsion gel

\begin{tabular}{lllll}
\hline Sr.No. & Parameters & F1 & F2 & F3 \\
\hline 1. & Appearance & Off-white & Off-white & Off-white \\
2. & pH & 6.59 & 6.23 & 6.72 \\
3. & Viscosity (cp) & 19.2 & 20.6 & 22.2 \\
4. & Globule size $(\mathrm{nm})$ & 269 & 263 & 260 \\
5. & Zeta potential $(\mathrm{mV})$ & -58.2 & -60.1 & -64.8 \\
6. & Spreadability $(\mathrm{s})$ & 40 & 37 & 34 \\
\hline
\end{tabular}

Table 3: In vitro drug release of F1-F3 formulation shows percentage of cumulative drug release

\begin{tabular}{llll}
\hline Time (h) & F1 & F2 & F3 \\
\hline 1 & $2.19 \pm 0.27$ & $2.82 \pm 0.47$ & $4.073 \pm 0.27$ \\
2 & $2.82 \pm 0.24$ & $3.52 \pm 0.47$ & $4.464 \pm 0.23$ \\
3 & $5.25 \pm 0.36$ & $6.34 \pm 0.71$ & $8.302 \pm 0.75$ \\
4 & $8.85 \pm 0.49$ & $10.65 \pm 0.72$ & $13.627 \pm 1.02$ \\
5 & $13.71 \pm 0.59$ & $16.14 \pm 1.06$ & $20.053 \pm 1.44$ \\
6 & $20.13 \pm 1.06$ & $23.50 \pm 1.41$ & $27.967 \pm 1.65$ \\
7 & $27.81 \pm 1.42$ & $32.28 \pm 1.80$ & $37.840 \pm 2.05$ \\
8 & $36.75 \pm 1.53$ & $42.86 \pm 2.03$ & $49.753 \pm 2.10$ \\
9 & $47.79 \pm 1.67$ & $55.55 \pm 2.18$ & $63.543 \pm 2.81$ \\
10 & $60.64 \pm 1.77$ & $70.05 \pm 2.62$ & $79.607 \pm 3.77$ \\
\hline
\end{tabular}

Release kinetics of optimized batch [16]

Model-dependent methods are based on different mathematical functions, which describe the dissolution profile. Mathematical modeling aids in predicting the drug release rates and diffusion behavior of these systems by the solution of an appropriate model, thereby reducing the number of experiments needed. The modeldependent approaches included as follows;

- Zero-order kinetic models.

- First-order kinetic model.

- Higuchi model.

- Korsmeyer-Peppas model (the power law).

- Hixson-Crowell model.

\section{Stability studies [17,18]}

The optimized batch is subjected to stability studies at $30^{\circ} \mathrm{C} \pm 2^{\circ} \mathrm{C}$ at $65 \% \mathrm{RH} \pm 5 \% \mathrm{RH}$ for duration of 3 months. Stability of the stored formulations was evaluated by visually inspecting the formulations for phase separation or turbidity.

\section{RESULTS AND DISCUSSION}

\section{Solubility studies}

Solubility of drug in different oils

The solubility of duloxetine $\mathrm{HCl}$ in various oils was analyzed to select oil for microemulsions.

The maximum amount of drug was found to be dissolved in oleic acid, i.e., $10 \mathrm{mg} / \mathrm{ml}$. Hence oleic acid was selected as oil phase for the formulation. As shown in Fig. 2. 

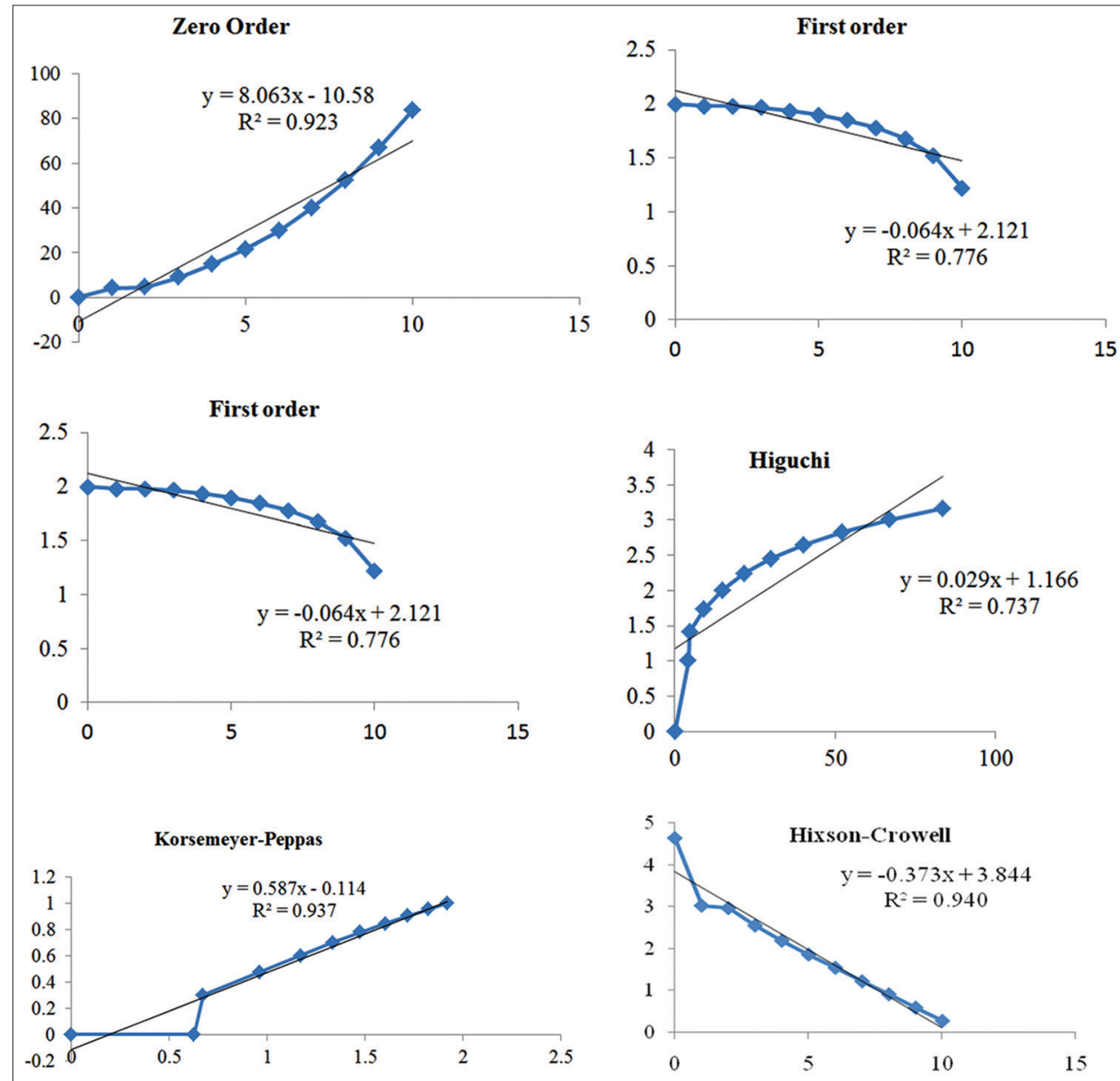

Fig. 9: (a-e) Release kinetic study of optimized batch F3

Table 4: Release kinetics of optimized batch F3

\begin{tabular}{lllllll}
\hline Batch no. & Zero-order & First order & Higuchi & Kors. Meyer peppas & Hix. crow & Best-fit model \\
\hline F3 & 0.9236 & 0.7769 & 0.7379 & 0.9375 & 0.9407 & Hix. crow \\
\hline
\end{tabular}

Table 5: Stability studies at $30^{\circ} \mathrm{C} \pm 2^{\circ} \mathrm{C}$ at $65 \% \mathrm{RH} \pm 5 \% \mathrm{RH}$ for 3 month

\begin{tabular}{llll}
\hline Parameters & 1 month & 2 month & 3 month \\
\hline Appearance & Off-white & Off-white & Off-white \\
pH & 6.71 & 6.70 & 6.71 \\
Viscosity (cp) & 21.8 & 21.9 & 22.1 \\
Globule size (nm) & 261 & 260 & 260 \\
Zeta potential (mV) & -64.7 & -64.6 & -64.7 \\
Spreadability (s) & 35 & 34 & 34 \\
\hline
\end{tabular}

\section{Solubility of dug in surfactants}

The solubility of duloxetine $\mathrm{HCl}$ in various surfactants was analyzed to select surfactant for microemulsions.

The maximum amount of drug was found to be dissolved in Tween 20, i.e. $132 \mathrm{mg} / \mathrm{ml}$. Hence, Tween 20 was selected as surfactant for the formulation. As shown in Fig. 3.

Solubility of drug in cosurfactants

The solubility of duloxetine $\mathrm{HCl}$ in various cosurfactants was analyzed to select cosurfactant for microemulsions.
The maximum amount of drug was found to be dissolved in propylene glycol, i.e., $234 \mathrm{mg} / \mathrm{ml}$. Hence, propylene glycol was selected as cosurfactant for the formulation. As shown in Fig. 4.

\section{Construction of ternary phase diagram}

Fig. 5 represents the pseudo-ternary phase diagrams of oleic acid with various ratios of Tween 20 and propylene glycol. It was found that the area of microemulsion became enlarged as the Smix reached (1:3) ratio.

\section{Characterization of microemulsion gel}

Physical appearance

The prepared gels were checked for their color, appearance, and consistency and were having a smooth, homogenous texture and offwhite appearance. As shown in Table 2.

\section{pH}

The $\mathrm{pH}$ of the formulations was found to be between 6.23 and 6.72. The results are shown in Table 2.

Viscosity

The viscosity of all three batches was measured using Brookfield Viscometer DV-II+PRO. The results are shown in Table 2. 


\section{Globule size and zeta potential}

The globule size and zeta potential were measured for all three batches. F3 batch showed optimum result. As shown in Table 2 and Figs. 6 and 7. Figs. 6 and 7 show particle size distribution and zeta potential of the formulation F3. The particle size of the microemulsion gel was found to be $260 \mathrm{~nm}$, and zeta potential was found to be $-64.8 \mathrm{mV}$ which indicates that the particles of microemulsion gel are negatively charged which provide electrostatic stabilization. The polydispersity index was found to be 0.594 which indicates narrow particle size distribution.

\section{Spreadability}

Spreadability of the formulations was determined. The results were shown in Table 2, indicating that the optimal gel formulations have shown good spreadability in $<1 \mathrm{~min}$.

\section{In vitro drug release of F1-F3 formulation shows percentage of cumulative drug release}

Drug release studies were performed using Franz diffusion cell employing a Millipore membrane. pH 7.4 phosphate buffer was used as the release medium. Drug release was found to be the highest for the formulation F3 $(79.607 \%)$ at $10^{\text {th }} \mathrm{h}$. As shown in Table 3 and Fig. 8.

Among all the batch, batch F3 showed a significant release as compared to other formulations.

\section{Release kinetics of optimized batch}

The Release kinetics of optimized batch F3 were studied, and the F3 batch showed higher correlation with Hixon-Crowell. The result was shown in Fig. 9 and Table 4.

\section{Stability studies}

The optimized batch was kept for stability studies at $30^{\circ} \mathrm{C} \pm 2^{\circ} \mathrm{C}$ at $65 \%$ $\mathrm{RH} \pm 5 \%$ RH for 3 months. As shown in Table 5 .

\section{CONCLUSION}

The study demonstrated that the microemulsion gel formulation can be employed to improve the stability of formulation and skin permeability of duloxetine $\mathrm{HCl}$. Microemulsion was prepared with oleic acid as oil, water, and $S_{\text {mix }}$ ratio of TWEEN 20: PG (1:3). F3 was found to be stable with the globule size of $260 \mathrm{NM}$ and percentage of drug release was found to be $79.607 \%$ in $10 \mathrm{~h}$ using carbopol $934 \mathrm{p}$ and HPMC K100 as the gelling agent. It can be concluded that microemulsion gel can be formulated successfully for duloxetine $\mathrm{HCl}$ with improved bioavailability. From stability data, the formulation was found to be stable as no phase separation or turbidity was observed in the formulation after 3 month.

\section{ACKNOWLEDGMENTS}

The authors would like to thank CTX Lifescience Pvt., Ltd., Gujarat, for providing us gift samples of the drug. They are thankful to Prof. (Dr.) Mrs. Sudha Rathod, Principal of Oriental College of pharmacy, Sanpada, Navi Mumbai, India provides all the facilities for this research Project. They are also thankful to Mr. S.K. Kar (Asst. Prof.) for helping in the process of procurement of the API.

\section{AUTHOR'S CONTRIBUTION}

The authors declare that this work was done by the authors named in this article and all liabilities pertaining to claims relating to the content of this article will be borne by the authors. Ms. Karishma Tole collected the data, analyzed the data, all the laboratory work performed, wrote the introduction, discussion and the material and method part. Dr. Ganesh Deshmukh proof-read the whole manuscript as well as helps in designing and conducting the study.

\section{CONFLICTS OF INTERESTS}

The authors declare that there is no conflict of interests regarding the publication of this paper.

\section{REFERENCES}

1. Chaiyana W, Phongpradist R, Leelapornpisid P, Anuchapreeda S. Microemulsion-based hydrogel for topical delivery of indomethacin. Int J Pharm Pharm Sci 2015;7:213-9.

2. Shingade GM, Aamer Q, Sabale PM, Grampurohit ND, Gadhave MV, Jadhav SL, et al. Review on: Recent trend on transdermal drug delivery system. J Drug Deliv Ther 2012;2:66-75.

3. Loyd V, Allen JR, Popovich NG, Ansel HC. Pharmaceutical Dosage Forms and Drug Delivery Systems. $8^{\text {th }}$ ed. Philadelphia, PA: LippincottWilliams and Wilkins; 2005. p. 298-9.

4. Kumar R, Philip A. Modified transdermal technologies: Breaking the barriers of drug permeation via the skin. Trop J Pharm Res 2007;6:633-44.

5. Rizwan M, Aqil M, Talegoankar S, Azeem A, Sultana Y, Ali A. Enhanced transdermal drug delivery techniques: An extensive review on patents. Recent Pat Drug Deliv Formul 2009;3:105-24.

6. Mishra A, Keshari AK, Singh AK, Maity S, Nandy B, Saha S. Oxidative stress-based hepatotoxicity of duloxetine in wistar rats. Int J Pharm Pharm Sci 2016;8:28-32

7. Kaur J, Nautiyal U, Kumar S, Singh D, Anwar F. Microemulsions: A potential novel drug delivery system. Int $\mathrm{J}$ Pharm Med Res 2014;2:15-20.

8. Beg S, Jena SS, Patra ChN, Rizwan M, Swain S, Sruti J, et al. Development of solid self-nanoemulsifying granules (SSNEGs) of ondansetron hydrochloride with enhanced bioavailability potential. Colloids Surf B Biointerfaces 2013;101:414-23

9. Dixit $\mathrm{P}$, Nagarsenker M. Self-nanoemulsifying granules of Ezetimibe: Design, optimization and evaluation. Eur J Pharm Sci 2008;35:183-92.

10. Patel J, Patel A, Raval M, Sheth N. Formulation and development of a self-nanoemulsifying drug delivery system of irbesartan. J Adv Pharm Technol Res 2011;2:9-16.

11. Kalhapure R, Krishnacharya G, Kamanchi A. Oleic acid based heterolipidsynthesis, characterization and application in selfmicroemulsifying drug deliver system. Int J Pharm 2012;425:9-18.

12. Patel RM, Patel BR, Parikh RJ, Bhatt KK, Solanki BA. Investigating the effect of vehicle on in vitro skin permeation of ketoconazole applied in O/W Microemulsions. Acta Pharm Sci 2010;52:65-77.

13. Madikattu K, Naidu KV, Srisailam K. Microemulsion based transdermal gels of isradipine to enhance bioavailability: In vitro and in vivo evaluation. Asian J Pharm 2016;9:23-30.

14. Wani RR, Patil MP, Dhurjad P, Chaudhari CA, Kshirsagar SJ. Microemulsion based gel: A novel approach in delivery of hydrophobic drugs. Int J Pharm Res Sch 2015;4:398-410.

15. Tirunagari M, Jangala VR, Khagga M, Gannu R. Transdermal therapeutic system of isradipine: Effect of hydrophilic and hydrophobic matrix on in vitro and ex vivo characteristics. Arch Pharm Res 2010;33:1025-33.

16. Shaikh HK, Kshirsagar RV, Patil SG. Mathematical models for drug release characterization: A review. World J Pharm Pharm Sci 2016;4:324-38.

17. Cartensen J., ICH Guidelines. Drug Stability Principles and Practices. $2^{\text {nd }}$ ed. New York: Marcel Dekker Inc.; 1995: 541-6.

18. U.S. Department of Health and Human Services FDA, Guidance for Industry Q1A (R2) Stability Testing Of New Drug Substances and Products, ICH Revision; 2003. p. 5 